IRA-International Journal of Applied Sciences ISSN 2455-4499; Vol.05, Issue 03 (2016)

Institute of Research Advances

Pg. no. $155-160$

http://research-advances.org/index.php/IRAJAS

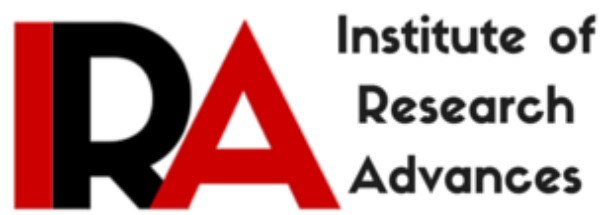

\title{
A Study to Identify the Factors Affecting the profitability of Contract Broiler Chicken Producers in the Poultry Belt of Sri Lanka
}

\section{Rifky A.L.M}

Postgraduate Institute of Agriculture,

University of Peradeniya, Peradeniya, Sri Lanka.

Type of Review: Peer Reviewed.

DOI: http://dx.doi.org/10.21013/jas.v5.n3.p6

\section{How to cite this paper:}

Rifky, A. (2016). A Study to Identify the Factors Affecting the profitability of Contract Broiler Chicken Producers in the Poultry Belt of Sri Lanka. IRA-International Journal of Applied Sciences (ISSN 2455-4499), 5(3), 155-160. doi:http://dx.doi.org/10.21013/jas.v5.n3.p6

(C) Institute of Research Advances

\section{(c) EY-NC}

This work is licensed under a Creative Commons Attribution-Non Commercial 4.0 International License subject to proper citation to the publication source of the work.

Disclaimer: The scholarly papers as reviewed and published by the Institute of Research Advances (IRA) are the views and opinions of their respective authors and are not the views or opinions of the IRA. The IRA disclaims of any harm or loss caused due to the published content to any party. 


\begin{abstract}
This study investigated the factors affecting the profitability of contract broiler chicken farmers in the poultry belt in Sri Lanka. One hundred contract (Buy Back) broiler producers in Kurunegala, Puttalam, Kalutara districts were randomly selected.The cost and return analysis of different sizes of out grower broiler producers were analyzed using the profit function approach Quantitative variables such as feed conversion ratio (FCR), mortality (\% per flock), input quantity and average body weight ( $\mathrm{kg} / \mathrm{bird})$, involvement in broiler farming (hours/month) were used in the analysis.

The investigated farmers were receiving a profit of $73.73 \pm 3.54$ Rs./bird. The other parameters were; average body weight of $1.9982 \pm 0.035 \mathrm{~kg} / \mathrm{bird}$, flock mortality of $3.564 \pm 0.324 \%$, and the FCR of $1.8038 \pm 0.017$. Regression analysis revealed that most important factors significantly ( $p-0.05)$ affecting profit in this study were the feed conversion ratio, input quantity, body weight and flock mortality. The contracting company provided inputs such as day old chicks (DOC), Transport, and incentives such as transport incentives, bird return incentives to improve the productivity, extension services to improve quality of production. FCR and Body weight are depending on the quality of feed and environmental conditions. Therefore, it is advisable to increase the input quantity to get optimum profits and to reduce the operational costs.
\end{abstract}

Key Words: Contract broiler production, Feed Conversion Ratio, Profit function

\title{
1.0 INTRODUCTION
}

This investigation was initiated to identify the most influencing factors affecting the profitability of the contract broiler chicken Producers. Broiler chicken is an important source of high quality protein, minerals and vitamins to balance the human diet. In meeting this demand at present; some of the leading poultry meat companies are using a technique called Buy Back System.

In tracing the history, in 1940s agricultural research brought in new technologies to the poultry industry such as; introduction of new breeds for meat, better nutrition, disease control, better management of confined poultry, processes that correctly sexed chicks and candling of eggs[2]. However, around $85 \%$ of feed raw material requirement are currently being imported increasing cost of production[4]. According to the Department of Animal Production and Health there have been fourteen large, medium and small scale feed manufacturers operating by the year of 2010 [1]. The production of poultry feed in 2010 was around 500 metric tons. The producer supplies the chicks, feed, medicine and vaccine and also arranges for veterinary supervision of the farms. The farmers are to provide the housing facilities, electricity, litter material and labor required for rearing the broiler to market age [5].

This system is having more benefits for producers and also to the company. They provide the input such as DOC, Feed, Vaccine and Drugs, also extension facilities and Buy Back the chicken after 39 to 42 days. Normally these farmers are having some profit. Now the companies are taking efforts to maximize the farmer's profit to expand the system. There are lots of contracting companies mainly having contract farms in the Kurunegala district where $60 \%$ of the Buy Back Farmers are involving on this system as per the current level of input. Factors affecting the profitability of the contract broiler chicken farmers in Sri Lanka will give definite advantages, in expanding this enterprise. Contracting companies started that the contract farmers were going away from farming and the reasons are not know. Therefore, this study is initiated. Factors such as feeding method, housing, supplementary feeding, management practices, disease, performances are considered in this investigation. Therefore, 100 farmers were selected to identify the factors affecting the profitability of the contract broiler chicken farmers in Sri Lanka.

\section{Objectives}

- Identify the factors affecting the profitability of the contract broiler meat farmers in Sri Lanka.

- Identify the cost and benefits of the broiler chicken production. 


\subsection{MATERIALS AND METHODS}

\subsection{Study area}

The study was conducted at some districts where contract farmers are populated in Sri Lanka. The farmers of contracting companies were located in different districts in Sri Lanka, where ideal climate for Broiler chicken production exist. The required data were obtained from 100 contract (Buy Back) broiler producers in Kurunegala, Putllam, Gampaha districts. Semi structured interviews were conducted with a pre-tested questionnaire. Contract broiler producers were directly interviewed with the presence of relevant field executives of the contracting companies to ensure the reliability and accuracy of data.

\subsection{Data Collection}

A comprehensive questionnaire was developed and conducted to collect the data. It was organized into nine major parts. Questions related to the Farmer identification, household labour allocation, purpose of production, sales, Expenditure, and farmer's knowledge on poultry production. Structured questionnaires (pre-tested) through interviews were used for data collection.

\subsection{Data Analysis}

Descriptive statistical analyses, 1-proportion test and multiple linear regression analysis were carriedout using Minitab 14 software, and Microsoft Excel 2010 software. First, a simple analysis (mean, standard error, frequency) was carried out.

\subsection{RESULTS AND DISCUSSION 3.1Socio-demographic}

Result shows that majority of the poultry farmers surveyed were Buddhists and Catholics $(52 \%$ and $40 \%$ respectively) and a small number of Muslims and Hindus (each 4\%) were involved in broiler chicken production. It indicates that the religious barrier is not a prominent factor for broiler chicken industry when compared with raising cattle or swine for meat.

\subsection{Involvement in farming}

Major activities in the farms were cleaning; maintaining the litter condition and adding feeds \& water to the chicken. Even though Family sizes of the broiler chicken producers were $3.64 \pm 0.237$ members; only $2.04 \pm 0.168$ members were involving in broiler production. It clearly shows the involvement in farming improving the profit of the farmers.

\subsection{Infra-Structure facilities}

Contracting company provides a guideline for preparing the poultry shed for contract broiler chicken production which was 1.20 Sq.feet per bird. Analysis showed that, average poultry shed size of $1.22 \pm$ 0.038 Sq.feet. Land availability is the limiting factor found with the contract broiler chicken producers as they did not have enough space for expansion. Construction of floor of the poultry unit is very important under the deep litter system. Deep litter requires proper insulation and durable floors. About $44 \%$ of the farmers used cemented floors while the rest had selected clay floors as an inexpensive alternative.

Survey analysis showed that majority of the farmers $(52 \%)$ preferred to use cadjan as a roofing material. $36 \%$ of the farmer preferred asbestos roofing materials and $8 \%$ of the farmer constructed their roofing with aluminum sheets which can be used for more than 30 batches/cycles. However, the initial cost for aluminum sheets is high.

Broiler producers were advised by the filed executives employed by the farmers and all the facilities with the company standards need to be. Feeding was according to the schedule provided by the contracting company. Almost all the farmers practiced minimum $3.5 \mathrm{~kg} / \mathrm{bird}$ of feed as mentioned in the schedule. All most all broiler producers are having water without any issues. It may be due to the strict criteria on water source requirements that are recommended by the company to start a new contract farms. Out of the selected farmers, $88 \%$ of them were found to have regular pipe water while 
the rest had to resort to wells as water supply is necessary for a poultry operation. Only $4 \%$ of the farms used pond water.

\subsection{Management practices}

Each cycle covered a period of 57-58 days, with the majority of 2000 DOC as an input quantity, while some farmers had the maximum capacity of 10,000 DOC. Survey analysis showed that majority of the farmers $(60 \%)$ were having a separate house for brooding which is a good practice for better bio-security. The Gas brooders were the major (64\%) type of brooding, $12 \%$ of the farmers used fire wood for brooding and $24 \%$ of the farmers had a electric bulb as a brooder. Company advised the farmers to have a gas brooder for better management and safety.

The survey results show that majority $(96 \%)$ of the farmers practiced good management procedures (ranked: very good $-16 \%$, good- $64 \%$, average-16\% ) with respect to feeders, drinkers, floor space per bird and family involvement. Mortality is an important factor because it is directly reducing the profit margin. The average mortality among the farms was $3.564 \pm 0.324 \%$. The mortality percentage up to age of slaughter varied among farms from $0.8 \%$ to a maximum of $7.6 \%$.

The additional income on the litter was found to be Rs. $0.584 \pm 0.113$ per bird. The survey results showed that feed conversion ratio among farms varied from 1.6700 to 1.9760 with a mean of $1.8038 \pm 0.0173$. Field executives of the contracting company mentioned that company calculating the FCR up to 4 decimal points, because each and every increase in the last digit will increase a considerable amount to the profit. The numbers of average visits of Field Executives to the farm were $2.920 \pm 0.172$, which was having a minimum of 2 visits and maximum of 4 visits according to the call and disease occurrences.

Mortality is very important in a farm because it directly reduces the profit margin. The average mortality among the farms was $3.564 \pm 0.324 \%$. The mortality percentage up to age of slaughter (39 to 40 days) varied among farms from $0.8 \%$ to a maximum of $7.6 \%$.

Lower the value of feed conversion ratio, higher will be the production efficiency in broiler farming. It means the birds consume less amount of feed to attain a given amount of live weight.

\section{Multiple Linear Regression}

Multiple linear regression analysis was carried out for the Net profit of the batch versus Average body weight, Flock mortality, input quantity and FCR. Model was developed from the previous study about contract farming [7].

The regression equation is

$Y=609065+42.1 X_{1}-325343 X_{2}-3876 X_{3}-12.8 X_{4}$

Y: Net Profit

$\mathrm{X}_{1}$ : Body Weight

$\mathrm{X}_{2:}$ Feed Conversion Ratio

$\mathrm{X}_{3:}$ Input Quantity

$\mathrm{X}_{4}$ : Flock mortality

\section{Constraints in farming}

High capital requirement for initial investment however has been a problem for many farmers. The above responses show that the buy-back process is operating satisfactorily as far as farmers are concerned.

Also the bank guarantee of Rs. 160.00 per bird for obtaining a contract for broiler farming is big problem for the farmers. The survey included information related to problems faced by the contract farmers with respect to operational activities of the buy-back system.

Contracting company provided high quality of veterinary and extension services to ensure high quality of service.. Average visit of Veterinary surgeon to the farm found to be $2.560 \pm 0.183$ which 
was having a minimum of 1 visit and maximum of 4 visits according to the call and disease occurrences. Average visit of Field Executives to the farm found to be $2.920 \pm 0.172$ which was having a minimum of 2 visits and maximum of 4 visits according to the call and disease occurrences.

\subsection{CONCLUSION}

The profitability of small scale Broiler farming depends on several factors. They are Feed Conversion Rate (FCR), Mortality and average body weight. Also found that increasing the input quantity will increase the profit by reducing the operational cost such as transportation of feed and day old chicks, electricity, labour charges.

\section{Acknowledgement}

I wish to convey my heartiest thanks to Professor H.W Cyril (Department of Animal Science, University of Peradeniya, Sri Lanka) for the continuous supervision and help provided during my research to complete the Master degree. Also I wish to convey my special thanks to field executives of contracting companies who were the key persons to support and guided me towards the farms to collect data.

\section{REFERENCES}

[1] Abeyrathne, A.S. (2007). A Review of the Livestock Industry of Sri Lanka.Department of Animal Production and Health, Peradeniya, Sri Lanka.

[2] Bandara.R.M.A.S. and Dassanayake, D.M.W.K.(2006). A quantitative analysis on factors affecting profitability of small scale broiler farmers. The Journal of Agricultural Science, 2(3): 45-50.

[3] Iddamalgoda, A.M.,Sugiyama.M.,Oguri.K., Arahata.K. andPremasiri.H.P. (1998). A study on development of Sri Lankan poultry.Importance of poultry sector. Res. Bull. Fac. Agricultural Science.Gifu University. 63: 87-96.

[4] MLRCD, (2011). The Livestock Sector in Sri Lanka.Ministry of Livestock and Rural Community Development, Colombo 03.http://www.livestock.gov.lk [Accessed on 11 August, 2011].

[5] Prabakaran, R. (2003). Good Practices in Planning and Management of Integrated Commercial Poultry Production in South Asia. FAO Animal Production and Health Paper 159.FAO, Rome, Italy.

[6] Ranga Reddy,P, Shanmugam, T. R. and Mohan, B. (1997). Economic and financial analysis of broiler production in Kamarajar District of Tamil Nadu. Journal Animal Sciences, 12(1): 119-122.

[7] Rifky A.L.M, Samaraweera A.M, Jayasinghe J.V.L.C, Mahipala M.B.P.K,: Factors Affecting on Milk Production of Contract Farmers of Swiss Cheese Company Private Limited in Nuwara-Eliya District. Research Symposium of Uva Wellassa University $-16^{\text {th }}$ and $17^{\text {th }}$ September 2010. 
(Tables \& Figures)

Table 3.1. Other income and expenses for our grower farmers

\begin{tabular}{lll}
\hline Description & $\begin{array}{l}\text { Last batch } \\
(\text { Mean } \pm \text { SE) / Per Bird }\end{array}$ & $\begin{array}{l}\text { Last batch(input size) } \\
(\text { Mean } \pm \text { SE) / Average }\end{array}$ \\
\hline Income from litter (+) & $0.584 \pm 0.113$ & $1,470 \pm 217$ \\
Electricity cost $(-)$ & $1.2782 \pm 0.086$ & $3,492 \pm 270$ \\
Veterinary services cost $(-)$ & $2.227 \pm 0.179$ & $6,387 \pm 805$ \\
\hline
\end{tabular}

Table.3.2 Productivity of the broiler producers

\begin{tabular}{lll}
\hline Description & $\begin{array}{l}\text { Last batch } \\
\text { (Mean } \pm \text { SE) / Per Bird }\end{array}$ & $\begin{array}{l}\text { Last batch } \\
\text { (Mean } \pm \text { SE) / Average } \\
\text { input size }\end{array}$ \\
\hline Total weight (kg) & $1.9982 \pm 0.035$ & $5,929 \pm 607$ \\
Flock FCR & $1.8038 \pm 0.017$ & $1.8038 \pm 0.017$ \\
Flock cumulative mortality \% & $3.564 \pm 0.324$ & $3.564 \pm 0.324$ \\
Company given profit (Rs) & $59.41 \pm 4.740$ & $184,669 \pm 25318$ \\
Incentives (Rs.) & $4.00 \pm 0.000$ & $11,880 \pm 1258$ \\
Allowances & $2.50 \pm 0.000$ & $7,870 \pm 724$ \\
\hline Net Profit (Rs.) & $\mathbf{7 3 . 7 3} \pm \mathbf{3 . 5 4}$ & $\mathbf{2 1 9 , 3 2 3} \pm \mathbf{2 4 , 2 1 4}$ \\
\hline
\end{tabular}

Table 3.3. Means, Minima and maxima of itemized costs and benefits of the poultry farmers surveyed.

\begin{tabular}{lll}
\hline Description & Qty of bags/1000 birds & Cost (Rs.)/1000 birds \\
\hline Booster & 9 & $35,005.14$ \\
Starter & 25 & $93,877.00$ \\
Finisher & 22 & $80,756.50$ \\
Withdrawal & 14 & $50,332.24$ \\
Feed Total & $\mathbf{7 0}$ & $\mathbf{2 5 9 9 7 0 . 8 8}$ \\
\hline Per Bird Feed Cost & & $\mathbf{2 5 9 . 9 7}$ \\
\hline
\end{tabular}

